\title{
ЕПІДЕМІОЛОГІЧНІ ОСОБЛИВОСТІ ПОШИРЕННЯ СПАДКОВОЇ МОТОРНО-СЕНСОРНОЇ НЕЙРОПАТІЇ В ПОЛТАВСЬКІЙ ОБЛАСТІ
}

\author{
○І. О. Говбах', Л. В. Молодан ${ }^{2,3}$, О. Я. Гречаніна ${ }^{2,3}$ \\ ${ }^{1}$ Харківська медична академія післядипломної освіти МОЗ України \\ ${ }^{2}$ Харківський національний медичний університет \\ ${ }^{3}$ Харківський міжсобласний спеціалізований медико-генетичний центр рідкісних (орфанних) захворювань
}

РЕзЮмЕ. Спадкова моторно-сенсорна нейропатія (СМСH) - це група клінічно та генетично неоднорідних нейропатичних розладів, які поширені по всьому світу й охоплюють усі етнічні групи. Показник поширеності СМСН нерівномірний у різних регіонах. Вивчення територіального та етнічного розподілу СМСН у Полтавській області не проводилося.

Мета - дослідження особливості поширення СМСН у Полтавській області в розрізі адміністративно-територіальних одиниць та окремих етнічних груп населення.

Матеріал і методи. Для дослідження епідеміологічних особливостей поширення СМСН у Полтавській області розраховували показник поширеності спадкової моторно-сенсорної нейропатії як для різних територіальноадміністративних одиниць Полтавської області, так і для окремих етнічних груп населення.

Результати. Показник поширеності всіх форм СМСН по Полтавській області становить 5,1. Високі значення показника поширеності СМСН у окремих районах області пов'язані з наявністю домінантного типу успадкування і багатодітністю сімей. У Полтавській області частка хворих на СМСН серед міського населення була вищою (64,9 \%), ніж серед жителів сільських районів $(35,1 \%)$. Виявлено також, що найвищі показники поширеності СМСН спостерігалися районах, що межують із сусідніми областями.

Висновки. Показник поширеності всіх форм СМСН по Полтавській області розподілений нерівномірно. Накопичення окремих форм СМСН у прикордонних зонах відображає вплив міграцій на формування структури генофонду і обтяженість спадковою патологією населення Полтавської області.

КЛючОВІ СлОВА: спадкова моторно-сенсорна нейропатія; Полтавська область; епідеміологія.

Вступ. Спадкові нейропатії - це різноманітна група захворювань, які класифікуються як синдромні, якщо вони є частиною системного захворювання, що вражає й інші органи, або несиндромні, коли нейропатія $\epsilon$ єдиним або основним проявом [8]. Демієлінізуючі нейропатії є результатом дисфункції генів, які в першу чергу впливають на шваннівські клітини, тоді як аксонні нейропатії дисфункції генів, що призводять до ураження переважно нейронів та аксонів. В останні роки використання так званого секвенування нового покоління (next-generation sequencing - NGS) привело до ідентифікації багатьох раніше невідомих генів та генетичних дефектів, які спричиняють нейропатію $[1,2]$. Розрізняють такі форми спадкових периферичних нейропатій: спадкова моторно-сенсорна нейропатія (хвороба Шарко - Марі - Тута), спадкова сенсорно-вегетативна нейропатія, спадкова моторна нейропатія та нейропатія тонких волокон [2]. Спадкові моторно-сенсорні нейропатії (CMCH) - це група клінічно та генетично неоднорідних нейропатичних розладів, які розповсюджені по всьому світу і охоплюють усі етнічні групи. $\mathrm{CMCH} \epsilon$ найпоширенішим спадковим нервовом'язовим розладом з приблизною частотою 1 на 2500 осіб [7]. Епідеміологічні дані демонструють, що СMCH трапляється частіше, ніж запальні або паранеопластичні нейропатії. Поширеність $\mathrm{CMCH}$ неоднорідна в різних країнах: наприклад, у Лівії на
100 тис населення - 8 випадків, Нігерії - 10, Південному Уельсі - 17, Північній Швеції - 20, Північній Icпанії- 28 [5].

Отже, зважаючи на те, що поширеність $\mathrm{CMCH}$ у різних популяціях варіює в широкому діапазоні, найактуальнішим на початковому етапі генетикоепідеміологічного дослідження $\mathrm{CMCH} \in$ визначення популяційної частоти цієї мутації в конкретному регіоні. Виявлення територіальних особливостей поширення, спектра і варіабельності проявів СМСН $€$ основою для створення ефективної системи їі моніторингу, а також розробки методів діагностики та профілактики, оптимальних для конкретного регіону. Дослідження регіональних епідеміологічних особливостей поширення $\mathrm{CMCH}$ також може сприяти раціональному розподілу наявних та потенційних ресурсів установами охорони здоров'я. Вивчення територіального та етнічного розподілу СМСН у Полтавській області не проводилося, що і обумовило мету проведення цього дослідження.

Мета - дослідження особливості поширення спадкової моторно-сенсорної нейропатії в Полтавській області в розрізі адміністративно-територіальних одиниць та окремих етнічних груп населення.

Матеріал і методи дослідження. Для вивчення особливостей поширеності спадкової моторно-сенсорної нейропатії (CMCH) у Полтавській 
Огляди літератури, оригінальні дослідження, погляд на проблему, випадок з практики, короткі повідомлення області використовували епідеміологічний метод вивчення захворюваності [3]. Епідеміологічне дослідження СМСН у Полтавській області проведено за зверненнями хворих у різні лікувально-профілактичні заклади в період з 2015 р. по 2020 р.

Діагноз СМСН був встановлений відповідно до рекомендацій Дослідницької групи ВООЗ з вивчення нервово-м'язових захворювань на підставі діагностичних критеріїв [4].

Показник поширеності спадкової моторно-сенсорної нейропатії розраховували як для різних територіально-адміністративних одиниць Полтавської області, так і для окремих етнічних груп населення за такою формулою:

$$
\text { Показник поширеності= } \frac{\text { кількість зареєстрованих хворих }}{\text { чисельність населення }} \cdot 100 \text { тис. }
$$

Дані щодо чисельності населення в різних територіально-адміністративних одиницях Полтавської області брали зі статистичного збірника Державної служби статистики України за 2015 рік, а інформацію щодо чисельності в окремих етнічних групах отримували з даних Всеукраїнського перепису населення 2001 року.

Описова статистика для якісних облікових ознак представлена у вигляді абсолютних значень і процентних часток.

Результати й обговорення. Чисельність населення Полтавської області відповідно до да- них Державної служби статистики України на 01.01.2015 р. становила 1448975 осіб, з них 553220 людей (38,2 \%) мешкали у сільській місцевості і 895755 (61,8 \%) - у міській.

Під час нашого дослідження зареєстровано 74 хворих на спадкову моторно-сенсорну нейропатію, які мешкали в Полтавській області: з них 19 (25,7 \%) - у м. Полтава та 55 (74,3 \%) - у Полтавській області.

Особливості поширення спадкової моторносенсорної нейропатії в м. Полтава та Полтавській області наведені в таблиці 1.

Таблиця 1. Поширеність спадкової моторно-сенсорної нейропатії в Полтавській області

\begin{tabular}{|c|c|c|c|c|c|}
\hline \multirow{2}{*}{$\begin{array}{c}\text { Найменування } \\
\text { територіально- } \\
\text { адміністративної одиниці }\end{array}$} & \multirow{2}{*}{$\begin{array}{c}\text { Загальна } \\
\text { чисельність } \\
\text { населення, осіб }\end{array}$} & \multicolumn{2}{|c|}{ Чисельність населення, осіб } & \multirow{2}{*}{$\begin{array}{c}\text { Показник } \\
\text { поширеності } \\
\text { СМСН }\end{array}$} & \multirow{2}{*}{$\begin{array}{c}\text { Кількість } \\
\text { хворих } \\
\text { СМСН }\end{array}$} \\
\hline & & міське & сільське & & \\
\hline 1 & 2 & 3 & 4 & 5 & 6 \\
\hline Полтавська область & 1448975 & 895755 & 553220 & 5,1 & 74 \\
\hline \multicolumn{6}{|c|}{ Міста обласного значення } \\
\hline Полтава & 294962 & 294962 & - & 6,4 & 19 \\
\hline Кременчук & 225216 & 225216 & - & 4,4 & 10 \\
\hline Комсомольськ & 52098 & 52098 & - & 9,5 & 5 \\
\hline Лубни & 47101 & 47101 & - & 4,2 & 2 \\
\hline Миргород & 40603 & 40603 & - & 4,9 & 2 \\
\hline \multicolumn{6}{|c|}{ Міста районного значення } \\
\hline Гадяч & 24129 & 24129 & - & 8,3 & 2 \\
\hline Глобине & 9820 & 9820 & - & - & - \\
\hline Гребінка & 10911 & 10911 & - & 9,2 & 1 \\
\hline Зіньків & 9856 & 9856 & - & - & - \\
\hline Карлівка & 15001 & 15001 & - & 13,3 & 2 \\
\hline Кобеляки & 9977 & 9977 & - & - & - \\
\hline Лохвиця & 11798 & 11798 & - & 17,0 & 2 \\
\hline Червонозаводське & 8472 & 8472 & - & - & - \\
\hline Пирятин & 15882 & 15882 & - & 12,6 & 2 \\
\hline Хорол & 13427 & 13427 & - & 7,4 & 1 \\
\hline \multicolumn{6}{|c|}{ Райони області } \\
\hline Великобагачанський & 25356 & 8340 & 1016 & 7,9 & 2 \\
\hline Гадяцький & 30223 & & 30223 & - & - \\
\hline Глобинський & 34654 & 6474 & 28180 & 8,7 & 3 \\
\hline Гребінківський ${ }^{*}$ & 11798 & & 11798 & 8,5 & 1 \\
\hline Диканський & 19072 & 7789 & 11283 & - & - \\
\hline Зіньківський & 25290 & 5410 & 19880 & - & - \\
\hline Карлівський* & 19255 & & 19255 & 5,2 & 1 \\
\hline
\end{tabular}


Огляди літератури, оригінальні дослідження, погляд на проблему, випадок з практики, короткі повідомлення

Продовження табл. 1

\begin{tabular}{|c|c|c|c|c|c|}
\hline 1 & 2 & 3 & 4 & 5 & 6 \\
\hline Кобеляцький & 32803 & 5095 & 27708 & 6,1 & 2 \\
\hline Козельщинський & 19780 & 6030 & 13750 & - & - \\
\hline Котелевський & 19703 & 12388 & 7315 & - & - \\
\hline Кременчуцький & 39735 & & 39735 & 7,6 & 3 \\
\hline Лохвицький & 31891 & 8472 & 23419 & - & - \\
\hline Лубенський & 32288 & & 32288 & - & - \\
\hline Машівський & 19723 & 3806 & 15917 & - & - \\
\hline Миргородський & 32590 & 5119 & 27471 & - & - \\
\hline Новосанжарський & 34846 & 8389 & 26457 & - & - \\
\hline Оржицький & 24367 & 5399 & 18968 & 4,1 & 1 \\
\hline Пирятинський & 16097 & & 16097 & 6,2 & 1 \\
\hline Полтавський & 67004 & & 67004 & 11,9 & 8 \\
\hline Решетилівський & 26540 & 9385 & 17155 & - & - \\
\hline Семенівський & 25741 & 6264 & 19477 & - & - \\
\hline Хорольський & 21611 & & 21611 & 9,3 & 2 \\
\hline Чорнухинський & 11616 & 2585 & 9031 & - & - \\
\hline Чутівський & 23128 & 9488 & 13640 & 8,6 & 2 \\
\hline Шишацький & 20566 & 4541 & 16025 & - & - \\
\hline
\end{tabular}

Примітка. * - чисельність населення без урахування міст обласного та районного підпорядкування.

Відповідно до результатів проведених досліджень, показник поширеності всіх форм спадкової моторно-сенсорної нейропатії в Полтавській області становить 5,1. Аналіз отриманих даних продемонстрував значну різницю між показниками поширеності СМСН у Полтавській області: від найнижчого - 4,1 в Оржицькому районі до найвищого - 17,0 у м. Лохвиця.

Слід відзначити неоднорідність поширення спадкової моторно-сенсорної нейропатії в різних районах Полтавської області. Найнижчі показники поширеності СМСН спостерігалися в таких містах і районах Полтавської області: Оржицький район $(4,1)$, м. Лубни $(4,2)$, м. Кременчук $(4,4)$ та м. Миргород $(4,9)$. Найвищі показники поширеності СМСН були в таких районах і містах: м. Лохвиця $(17,0)$, м. Карлівка $(13,3)$, м. Пирятин $(12,6)$ і Полтавський район $(11,9)$.

Загалом показник поширеності СМСН у містах районного та обласного значення був вищий, ніж у районах області. СМСН виявлена у всіх п'яти містах
(100 \%) обласного значення: Полтава, Кременчук, Комсомольськ, Лубни, Миргород; у 6 містах (60 \%) районного значення: Гадяч, Гребінка, Карлівка, Лохвиця, Пирятин; в 11 (44 \%) адміністративних районах Полтавської області: Великобагачанський, Глобинський, Гребінківський, Карлівський, Кобеляцький, Кременчуцький, Оржицький, Пирятинський, Полтавський, Хорольський, Чутівський.

64,9 \% (48 осіб) хворих СМСН у Полтавській о6ласті $\epsilon$ міськими жителями і 35,1 \% (26 осіб) мешкають у сільській місцевості. При чисельності міського населення в Полтавській області 895755 осіб (61,82 \%) і сільського населення 553220 (38,18 \%), відповідно, частка осіб міського населення серед хворих СМСН у Полтавській області суттєво вища, ніж сільських жителів.

У нашому досліджені також був проведений аналіз поширеності спадкової моторно-сенсорної нейропатії в Полтавській області за етнічними групами. У таблиці 2 представлений розподіл за етнічними групами хворих на СМСН у Полтавській області.

Таблиця 2. Розподіл за етнічними групами хворих на спадкову моторно-сенсорну нейропатію в Полтавській області

\begin{tabular}{|l|c|c|c|c|c|}
\hline Етнічна група & $\begin{array}{c}\text { Чисельність } \\
\text { етнічної групи, } \\
\text { осіб }\end{array}$ & $\begin{array}{c}\text { Частки етнічних } \\
\text { груп у загальній } \\
\text { структурі } \\
\text { населення, \% }\end{array}$ & $\begin{array}{c}\text { Кількість хворих } \\
\text { на СМСН в етніч- } \\
\text { ній групі, осіб }\end{array}$ & $\begin{array}{c}\text { Показник поши- } \\
\text { реності СМСН в } \\
\text { етнічній групі }\end{array}$ & $\begin{array}{c}\text { Частки хворих у } \\
\text { загальній структу- } \\
\text { рі хворих СМСН, } \\
\%\end{array}$ \\
\hline Українці & 1324363 & 91,4 & 70 & 4,72 & 94,6 \\
\hline Росіяни & 104326 & 7,2 & 4 & 3,42 & 5,4 \\
\hline
\end{tabular}

Етнічний склад хворих на СМСН у Полтавській області однорідний: 94,6% (70 осіб) є українцями і 5,4\% (4 особи) - росіянами. Виявлений розподіл хворих на СМСН у Полтавській області за етніч- 
Огляди літератури, оригінальні дослідження, погляд на проблему, випадок з практики, короткі повідомлення ним складом можна порівняти з етнічною структурою населення: 91,4 \% (1 324363 ) українців і 7,2% (104 326) росіян; на частку інших національностей в Полтавській області припадає 1,4% населення (20 286 осіб).

Проведений клініко-генеалогічний аналіз хворих на СМСН у Полтавській області дозволив встановити, що у 28 пацієнтів (37,8 \% випадків) захворювання було представлено єдиним хворим у сім'ї.

Результати нашого дослідження продемонстрували, що в Полтавській області частка хворих на СМСН серед міського населення вища, ніж серед жителів сільських районів. Вищий відсоток виявлення захворювання на спадкову моторно-сенсорну нейропатію в містах можна пояснити наявністю в них висококваліфікованих кадрів, спеціалізованих медичних установ з розширеними можливостями проведення високотехнологічних методів діагностики.

Під час аналізу причин значної різниці між показниками поширеності СМСН у Полтавській області встановлено, що головним чинником може бути відмінність чисельності населення окремих

\section{ЛІТЕРАТУРА}

1. Dohrn M. F. Hereditary motor neuropathies / M. F. Dohrn // Current opinion in neurology. - 2020. Vol. 33, No. 5. - P. 568-574. URL: https://doi.org/10.1097/ WCO.0000000000000848

2. Eggermann K. Hereditary Neuropathies / K. Eggermann // Deutsches Arzteblatt international. - 2018. Vol. 115, No. 6. - P. 91-97. URL: https://doi.org/10.3238/ arztebl.2018.0091

3. Lash T. L. Modern Epidemiology, 4th Edition / T. L. Lash. - Wolters Kluwer, 2021. - 1199 p.

4. Lehmann H. C. Diagnosis of peripheral neuropathy / H. C. Lehmann // Neurological research and practice. 2020. - Vol. 2, No. 20. - P. 1-7. URL: https://doi.org/10.1186/ s42466-020-00064-2

\section{REFERENCES}

1. Dohrn, M.F., \& Saporta, M. (2020). Hereditary motor neuropathies. Current Opinion in Neurology, 33(5), 568574. https://doi.org/10.1097/WCO.0000000000000848

2. Eggermann, K., Gess, B., Häusler, M., Weis, J., Hahn, A., \& Kurth, I. (2018). Hereditary Neuropathies. Deutsches Arzteblatt International, 115(6), 91-97. https:// doi.org/10.3238/arztebl.2018.0091

3. Lash, T.L., VanderWeele, T.J., Haneuse, S., \& Rothman, K.J. (2021). Modern Epidemiology, 4th Edition, Wolters Kluwer.

4. Lehmann, H.C., Wunderlich, G., Fink, G.R., \& Sommer, C. (2020). Diagnosis of peripheral neuropathy. Neurological Research and Practice, 2(20), 1-7. https://doi. org/10.1186/s42466-020-00064-2

районів («ефект малих вибірок»).

Також слід зазначити, що високі значення показника поширеності СМСН у окремих районах області пов'язані з наявністю домінантного типу успадкування і багатодітністю сімей [6].

Виявлено також, що найвищі показники поширеності СМСН спостерігалися в прикордонних із сусідніми областями районах. Так, наприклад, найвищий показник 17,0 зафіксовано в м. Лохвиця, яке межує з Сумською областю; інший високий показник спостерігався в М. Карлівка, що на кордоні з Харківською областю; у м. Пирятин, що на кордоні з Київською областю.

Висновки. Показник поширеності всіх форм СМСН у Полтавській області розподілений нерівномірно. Накопичення окремих форм СМСН у прикордонних зонах відображає вплив міграцій на формування структури генофонду і обтяженість спадковою патологією населення Полтавської області.

Перспективи подальших досліджень полягають у вивченні клініко-неврологічних характеристик спадкової моторно-сенсорної нейропатії.

5. Nagappa M. Charcot Marie Tooth / M. Nagappa. In StatPearls. StatPearls Publishing, 2021.

6. Pipis M. Next-generation sequencing in Charcot-Marie-Tooth disease: opportunities and challenges / M. Pipis // Nature reviews. Neurology. - 2019. - Vol. 15, No. 11. - P. 644656. URL: https://doi.org/10.1038/s41582-019-0254-5

7. Rudnik-Schöneborn S. Charcot-Marie-Tooth disease and hereditary motor neuropathies - Update 2020 / S. Rudnik-Schöneborn // Medizinische Genetik. - 2020. Vol. 32, No. 3. - P. 207-219. URL: https://doi.org/10.1515/ medgen-2020-2038

8. Stavrou M. Genetic mechanisms of peripheral nerve disease / M. Stavrou // Neuroscience letters. 2021.-Vol.742.-P.135357.URL: https://doi.org/10.1016/j. neulet.2020.135357

5. Nagappa, M., Sharma, S., \& Taly, A.B. (2021). Charcot Marie Tooth. In StatPearls. StatPearls Publishing.

6. Pipis, M., Rossor, A.M., Laura, M., \& Reilly, M.M. (2019). Next-generation sequencing in Charcot-Marie-Tooth disease: opportunities and challenges. Nature Reviews Neurology, 15(11), 644-656. https://doi.org/10.1038/s41582019-0254-5

7. Rudnik-Schöneborn, S., Auer-Grumbach, M. \& Senderek, J. (2020). Charcot-Marie-Tooth disease and hereditary motor neuropathies - Update 2020. Medizinische Genetik, 32(3), 207-219. https://doi.org/10.1515/medgen-2020-2038

8. Stavrou, M., Sargiannidou, I., Christofi, T., \& Kleopa, K.A. (2021). Genetic mechanisms of peripheral nerve disease. Neuroscience Letters, 742, 135357. https://doi. org/10.1016/j.neulet.2020.135357 
Огляди літератури, оригінальні дослідження, погляд на проблему, випадок з практики, короткі повідомлення

EPIDEMIOLOGICAL FEATURES OF HEREDITARY MOTOR AND SENSORY NEUROPATHY

DISTRIBUTION IN THE POLTAVA REGION

\author{
OI. O. Govbakh1, L. V. Molodan ${ }^{2,3}$, O. Ya. Grechanina ${ }^{2,3}$ \\ ${ }^{1}$ Kharkiv Medical Academy of Postgraduate Education, Ministry of Public Health of Ukraine \\ ${ }^{2}$ Kharkiv National Medical University \\ ${ }^{3}$ Kharkiv Interregional Specialized Medical Genetic Center of Rare (Orphan) Diseases
}

SUMMARY. Hereditary motor and sensory neuropathy (HMSN) is a group of clinically and genetically heterogeneous neuropathic disorders that are common throughout the world and encompass all ethnic groups. The prevalence of HMSN is unevenly distributed across regions. The study of the territorial and ethnic distribution of HMSN in the Poltava region was not carried out.

The aim - to study the epidemiological features of HMSN in the Poltava region in the context of administrative and territorial units and individual ethnic groups of the population.

Material and Methods. To study the epidemiological features of the distribution of HMSN in the Poltava region, the prevalence rate of hereditary motor-sensory neuropathy was calculated both for various administrative and territorial units of the Poltava region and for individual ethnic groups of the population.

Results. The prevalence rate of all forms of HMSN in the Poltava region is 5.1. The high values of the prevalence of HMSN in certain districts of the Poltava region is associated with the presence of a dominant type of inheritance and large families. In the Poltava region, the proportion of patients with HMSN among the urban population was higher (64.9\%) than among residents of country areas (35.1\%). It was also revealed that the highest prevalence rates of HMSN were observed in areas bordering with neighboring regions.

Conclusions. The prevalence rate of all forms of HMSN in the Poltava region is unevenly distributed. The accumulation of individual forms of HMSN in the border zones reflects the influence of migrations on the formation of the structure of the gene pool and the burden of hereditary pathology of the population of the Poltava region.

KEY WORDS: hereditary motor sensory neuropathy; Poltava region; epidemiology. 